\section{Stability and Adaptability of Cotton (Gossypium Hirsutum L.) Genotypes under Multi Environmental Conditions in Mozambique}

\author{
Maleia $\mathrm{MP}^{1 *}$, Jamal $\mathrm{EC}^{2}$, Savanguane $\mathrm{JW}^{3}$, João $\mathrm{J}^{1}$ and Teca \\ $\mathrm{JO}^{1}$
}

${ }^{1}$ Instituto de Investigação Agrária de Moçambique, Maputo, Mozambique

${ }^{2}$ Instituto do Algodão de Moçambique, Maputo, Mozambique

${ }^{3}$ Universidade Catolica de Moçambique, Faculdade de Agricultura, Cuamba, Mozambique

\begin{abstract}
Cotton (Gossypium hirsutum), is an important crop in many developing countries. The crop yield is fundamentally dependent on the environment in which it is grown. One of the major challenges for cultivar recommendation is the genotype by environment interaction when the performance ranking of genotypes over environments is not constant. The identification of cultivars with high adaptability and stability to the growing conditions is an option to deal with this fact. The objective of the present study was to assess the yield stability and adaptability of cotton (Gossypium hirsutum L.) genotypes under multi environmental conditions in Mozambique. The trials were established over two years (2014/15 and 2015/16) in Namialo, Cuamba and Balama, in a total of six environments. The plots were established in a randomized complete block design with three replicates of eighteen treatments. The stability and adaptability were assessed using the AMMI (Additive Main Effect and Multiplicative Interaction) multivariate method. The results showed that the most productive new genotype in terms of seed cotton yield was IP63. Among the introduced new genotypes, the Brazilian IMACD
\end{abstract}

*Corresponding author: Maleia MP, Instituto de Investigação Agrária de Moçambique, Maputo, Mozambique, Tel: +258 82876040/8445588271; E-mail: mmaleia@gmail.com

Citation: Maleia MP, Jamal EC, Savanguane JW, João J, Teca JO (2019) Stability and Adaptability of Cotton (Gossypium Hirsutum L.) Genotypes under Multi Environmental Conditions in Mozambique. J Agron Agri Sci 2: 017.

Received: December 20, 2019; Accepted: December 24, 2019; Published: December 31, 2019

Copyright: ( 2019 Maleia MP, et al. This is an open-access article distributed under the terms of the Creative Commons Attribution License, which permits unrestricted use, distribution, and reproduction in any medium, provided the original author and source are credited.
06-6798 were classified as the most stable followed by the other Brazilian IMA1 08-3917 and the Turkish BA 919 compared to the local CIMSAN1 and the Zambian Churedza. The results suggest that the genotypes IMACD 06-6798, IMA1 08-3917 and BA 919 may be recommended for cultivation in Mozambique, since they presented an acceptable adaptability and potential stability.

Keywords: AMMI; Biplot; Genotype X environment interaction; Multivariate analysis; Stability; Triplot; Yield

\section{Introduction}

Cotton (Gossypium hirsutum L.), is an important commodity in the world, including in many developing countries. This crop is grown in more than 100 countries. India, China and USA are the main produces in the world [1]. Mozambique is not a big cotton producer country, but cotton assumes a great importance among small scale farmers in rural areas, where involves more than 300.000 families in its production as a cash crop and is the most important agricultural export crop in the country contributing close to 17 percent of total agricultural exports and almost 2 percent of total exports [2,3]. In addition, 10 professional companies have cotton as their core business and create over 20.000 employments throughout it value chain, namely seasonal and permanent workers. Cotton ranks second in merchandise exports Small-scale farmers, comprising 99 percent of all rural households in Mozambique and provide 95 percent of agricultural gross domestic product, where the country's rural economy is heavily reliant on the cotton subsector. This subsector generates nearly 40 million USD in agriculture exports per year [3]. The yield of this cash crop is particularly low in the whole country $\left(500 \mathrm{~kg}^{-} \mathrm{ha}^{-1}\right)$ compared to the world average yield $\left(800 \mathrm{~kg} \cdot \mathrm{ha}^{-1}\right)$ and to the neighboring countries such as Malawi (800 kg.ha-1 $)$, Tanzania (750 kg.ha $\left.{ }^{-1}\right)$ and Zambia (800 kg.ha $\left.{ }^{-1}\right)$ $[2,4]$. One of the reasons is the low yielding and less adaptable varieties [5]. The cotton research program in the country has been developing and introducing new different germplasm/genotypes, in order to find the suitable varieties to the local edaphoclimatic conditions [5]. However, recommendation of varieties has been a challenge, as it depends largely on the variety adaptability to the soil and climatic conditions of the region where it will be grown and unpredictable weather patterns cause a need for the identification of stable genotypes that have specific adaptation to specific environments [6]. In the previous seasons (2014/15 and 2015/15), Mozambique introduced and evaluated new germoplasms from Brazil, Turkey and China, compared to those grown in the country. This study aimed to assess the yield stability and adaptability of the new cotton (Gossypium hirsutum L.) genotypes under multi-environmental conditions in Mozambique.

\section{Material and Methods}

\section{Location and seasons}

The genotypes were evaluated comparing the used cultivars, during 2 seasons (2014/15 and 2015/16) in Namialo (14S 58' 00 and 39E 51'00) district of Meconta, province of Nampula; Namara 
(13S 22' 58 and 38E 25' 13) district of Balama, province of Cabo Delgado and in Cuamba (14S59'99 and 36E59'99), district of Cuamba, province of Niassa; providing 6 different environments through the combination between locals and seasons (Table 1).

\begin{tabular}{|c|c|l|l|}
\hline Environment & \multicolumn{2}{|c|}{ Season/Year } & \multicolumn{1}{c|}{ Local } \\
\hline Env 1 & \multicolumn{2}{|c|}{$14 / 15$} & Namialo \\
\hline Env 2 & \multicolumn{2}{|c|}{$14 / 15$} & \multicolumn{2}{c|}{ Cuamba } \\
\hline Env 3 & \multicolumn{2}{|c|}{$15 / 16$} & Namialo \\
\hline Env 4 & \multicolumn{2}{|c|}{$15 / 16$} & Cuamba \\
\hline Env 5 & \multicolumn{2}{|c|}{$15 / 16$} & Balama \\
\hline Env 6 & \multicolumn{2}{|c|}{$15 / 16$} & Cuamba \\
\hline Local & Namialo & Balama & Cuamba \\
\hline District & Meconta & Balama & Niassa \\
\hline Province & Nampula & Cabo Delgado & Humid tropical \\
\hline Climate type & Semi-humid & Semi-arid & Hoam \\
\hline Soil & Sandy loam & Alluvium & Loam \\
\hline
\end{tabular}

Table 1: Locals description and seasons where the multi-environment trials were laid out.

\section{Experimental design}

The treatments (Table 2), were set up in a randomized complete block design, with three replications. The plots were consisted of three rows of $5.0 \mathrm{~m}$ length, where the two lateral rows were considered as side borders and the central as the useful one, where the data was collected, in a spacement of $0.70 \mathrm{~m}$ between the rows and $0.20 \mathrm{~cm}$ between the plants. Sowing was carried out manually, putting 4-10 seeds per hole of about $4 \mathrm{~cm}$ of depth. The first thinning took place 15 days after the emergency, leaving two plants per hole and the second thinning was carried out leaving one plant per hole at 21 days after the emergency.

\begin{tabular}{|c|c|c|c|c|c|}
\hline \multirow[b]{2}{*}{$\begin{array}{l}\text { Treat- } \\
\text { ment }\end{array}$} & \multirow[b]{2}{*}{ Genotype } & \multirow[b]{2}{*}{ Origin } & \multirow[b]{2}{*}{$\begin{array}{l}\text { Conti- } \\
\text { nent }\end{array}$} & \multicolumn{2}{|c|}{ Agronomic description } \\
\hline & & & & Cycle & $\begin{array}{l}\text { Leaves and } \\
\text { Stem pu- } \\
\text { bescence }\end{array}$ \\
\hline 1 & ALBAR SZ 9314 & Zimbabwe & Africa & Late & Medium \\
\hline 2 & BA919 & Turkey & Europe & Medium & Medium \\
\hline 3 & CA324 & Mozambique & Africa & Late & Medium \\
\hline 4 & CHUREDZA & Zambia & Africa & Medium & Medium \\
\hline 5 & CIMSAN 1 & Mozambique & Africa & Medium & High \\
\hline 6 & FK 37 & Burkina Fasso & Africa & Medium & Medium \\
\hline 7 & FLASH & Turkey & Europe & Medium & Medium \\
\hline 8 & IMA1 -08-3917 & Brazil & America & Medium & Medium \\
\hline 9 & IMA1 09-1708 & Brazil & America & Medium & Medium \\
\hline 10 & IMA1 09-278 & Brazil & America & Medium & Medium \\
\hline 11 & IMACD 058221 & Brazil & America & Medium & Medium \\
\hline 12 & IMACD 06-6798 & Brazil & America & Medium & Medium \\
\hline 13 & IMACD 8276 & Brazil & America & Medium & Medium \\
\hline 14 & IMACD07-6372 & Brazil & America & Medium & Medium \\
\hline 15 & IMAIAC 26 & Brazil & America & Medium & Medium \\
\hline 16 & IP 60 & China & Asia & Early & Fair \\
\hline 17 & IP 63 & China & Asia & Early & Fair \\
\hline 18 & IP 75 & China & Asia & Early & Fair \\
\hline
\end{tabular}

\section{Management and evaluated variables}

Weeds were controlled manually using a hoe whenever deemed necessary. Spraying was carried out once with acetamiprid insecticide ( $\left.222 \mathrm{~g} \mathrm{lt}^{-1}\right)$ for the first control of pests in a dosage of $50 \mathrm{ml} \cdot \mathrm{ha}^{-1}$, followed by five applications of Lambda-cihalothrin $\left(60 \mathrm{~g} \mathrm{~L}^{-1}\right)$ every two weeks from the fourth week after the emergency, in a dosage of $250 \mathrm{ml} \cdot \mathrm{ha}^{-1}$. Insecticides were applied with a micro-ulva (ULV). The variables evaluated were the seedcotton yield $\left(\mathrm{Kg}_{\mathrm{g}} \mathrm{ha}^{-1}\right)$ and ginning outturn (\%).

\section{Statistical Analysis}

Before the Analysis of Variance (ANOVA), the data was submitted to tests of homogeneity of variances and normality $[7,8]$ to ensure the feasibility of ANOVA. For the Individual ANOVA, every combination of local and season/year was regarded as an environment. Before conducting the combine ANOVA, the assessment of homogeneity of the residual variances of the environments was conducted, using the Hartley's Fmax test [9], at 5\% of probability, to ensure the feasibility of combine analysis of variance [10]. The combine ANOVA was conducted after the residual variances of all the environments were regarded as homogeneous $(p>0.05)$, considering the effect of genotypes as fixed, and the effect of the environments and blocks as random [10]. When a significant Genotypes x Environments (GxE) interaction was revealed, stability and adaptability analysis based on the AMMI (Additive Main Effects and Multiplicative Interaction) model were applied, where the original GxE interaction was decomposed into the principal component analysis [11-14].

\section{Results and Discussion}

Shapiro-Wilk's normality of the error [8] and Bartlett's homogeneous variance of errors [7] for the seed cotton yield allowed preceding the individual ANOVA in each of six environments. Then, the assessment of the Hartley's Fmax test [9] indicated homogeneous error variances among the evaluated environments that allowed conducting the combined ANOVA. The combined ANOVA revealed a significant difference among genotypes, environments for both evaluated variables and a significant GxE interaction for seed cotton yield, while the GxE interaction for ginning outturn was not significant (Table 3), which indicates that the environment had an impact over the differentiated performance of the genotypes and the broad range of diversity among them [15]. This is the same from that found by Maleia et al. [5], Pretorius et al. [6] and Maleia et al. [16], when evaluating cotton genotypes in different environments. In addition, it shows that some varieties had better performance in one environment and low performance in others, which provided a change of their performance standard under the environmental variation revealed by the significant of GxE interaction for seed cotton yield (Table 3). This is often observed when studying any complex (multigenic) trait, such as seed cotton yield, a trait governed by multiple genes that cause changes in the performance of genotypes over different environments. Similar significant effects of genotype and GxE interaction for seedcotton yield were observed by Maleia et al. [5], Pretorius et al. [6], Maleia et al. [16], when evaluating cotton genotypes in multi-environmental trials in Mozambique, Pakistan, South Africa and Brazil. 
Citation: Maleia MP, Jamal EC, Savanguane JW, João J, Teca JO (2019) Stability and Adaptability of Cotton (Gossypium Hirsutum L.) Genotypes under Multi Environmental Conditions in Mozambique. J Agron Agri Sci 2: 017.

\begin{tabular}{|c|c|c|c|}
\hline \multirow{2}{*}{ Source of Variation } & \multirow{2}{*}{ DF } & \multicolumn{2}{|c|}{ Mean Square } \\
\cline { 3 - 4 } & & $\mathbf{C S Y}(\mathbf{k g} / \mathbf{h a})$ & $\mathbf{G O T}$ (\%) \\
\hline Blocks/Environment & 2 & 507360.8 & 12.73089 \\
\hline Environments (E) & 5 & $35731792.2^{* *}$ & $137.2884^{* *}$ \\
\hline Genotypes (G) & 17 & $839548.4^{* *}$ & $48.77634^{* *}$ \\
\hline G x E & 85 & $524928.6^{*}$ & 13.60928 \\
\hline Residue (Error) & 214 & 362432.7 & 11.99569 \\
\hline Total & 323 & & \\
\hline Overall Mean & & 2049.392 & 39.58936 \\
\hline CV (\%) & & 29.37573 & 8.748512 \\
\hline
\end{tabular}

Table 3: Summary of combine ANOVA of seed cotton yield $\left(\mathrm{Kg}\right.$ ha $\left.{ }^{-1}\right)$ and Ginning Outturn (\%).

** Significant at $1 \%$ of probability, ${ }^{*}$ Significant at $5 \%$ of probability CSY: Cottonseed Yield; FY: Fiber Yield; GOT: Ginning Outturn.

The decomposition of GxE interaction into principal components (Table 4), among which the first three (PC1, PC2 and PC3) were significant $(\mathrm{p}<0.01)$, explained about $80 \%$ of the detected interaction ( $33.85 \% ; 61.60 \%$ and 18.16 for PC1 and PC2, respectively), which makes the stability and adaptability study based on the AMMI method more concise [12].

\begin{tabular}{|c|c|c|c|c|c|}
\hline \multicolumn{3}{|c|}{ Source of variation } & \multirow[t]{2}{*}{ DF } & \multirow[t]{2}{*}{ SS } & \multirow[t]{2}{*}{ MS } \\
\hline Interaction $(\mathrm{G} \times \mathrm{E})$ & $\%$ & Accumulated \% & & & \\
\hline $\begin{array}{l}\text { Principal Compo- } \\
\text { nents }\end{array}$ & 33.85 & 33.85 & 21 & 20136668.37 & 958888.97* \\
\hline PC1 & 27.75 & 61.60 & 19 & 16509778.57 & $868935.71 *$ \\
\hline $\mathrm{PC} 2$ & 18.16 & 79.76 & 17 & 10803671.80 & $635510.23 *$ \\
\hline $\mathrm{PC} 3$ & - & - & & 77560587.20 & 362432.70 \\
\hline Residue (Error) & & & & & \\
\hline
\end{tabular}

Table 4: Decomposition of GxE interaction of seed cotton yield into principal components.

The AMMI Triplot Graphic (Figure 1), emphasizes that there were a year to year variation indicating the importance of seasonal climatic variation in the same local, as many environments were scatted without any grouping on different quadrants [15]. Maleia et al, [16], found out the similar results when studying the genotype by Environment interaction of different genotypes in Mozambique. The environmental conditions of cotton growing regions in Mozambique are highly diversified and it leads to cultivar environmental variability. Gul et al. [17], studied the genotype by environment interaction and association of yield variables in cotton and found that the seed cotton yield is highly affected by environment complex than genotype itself. So identification of genotypes with high adaptability and stability to the different growing conditions is an option to deal with this fact. Among the introduced new genotypes, the Brazilian IMACD 06-6798 were classified as the most stable followed by the other Brazilian IMA1 08-3917 and the Turkish BA 919 compared to the local CIMSAN 1 and the Zambian Churedza (Figure 1).

Results showed that the Chinese genotype IP 63 were the most productive compared to other evaluated genotypes and the most productive local were Cuamba in the two seasons, 2014/15 and 2015/16 (Figure 2).

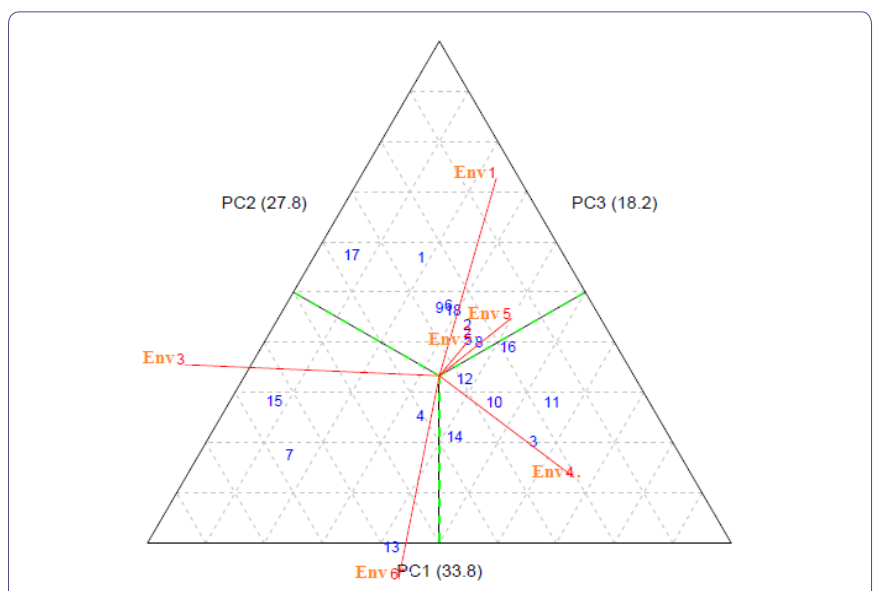

Figure 1: Graphic triplot of PC1, PC2 and PC3 of 18 genotypes in 6 environments for Seedcotton yield.

1. ALBAR SZ 9314; 2. BA919; 3. CA324; 4. CHUREDZA; 5. CIMSAN 1; 6. FK37; 7. FLASH; 8. IMA1 -08-3917; 9. IMA1 09-1708; 10. IMA1 09-278; 11. IMACD 058221; 12. IMACD 06-6798; 13. IMACD 8276; 14. IMACD07-6372; 15. IMAIAC 26; 16. IP 60; 17. IP 63; 18.IP75.

ENV1: Namialo 2014/15; ENV2: Balama 2014/15; ENV3: Cuamba 2014/15; ENV4: Namialo 2015/16; ENV5: Cuamba 2015/16; ENV6: Balama 2015/16.

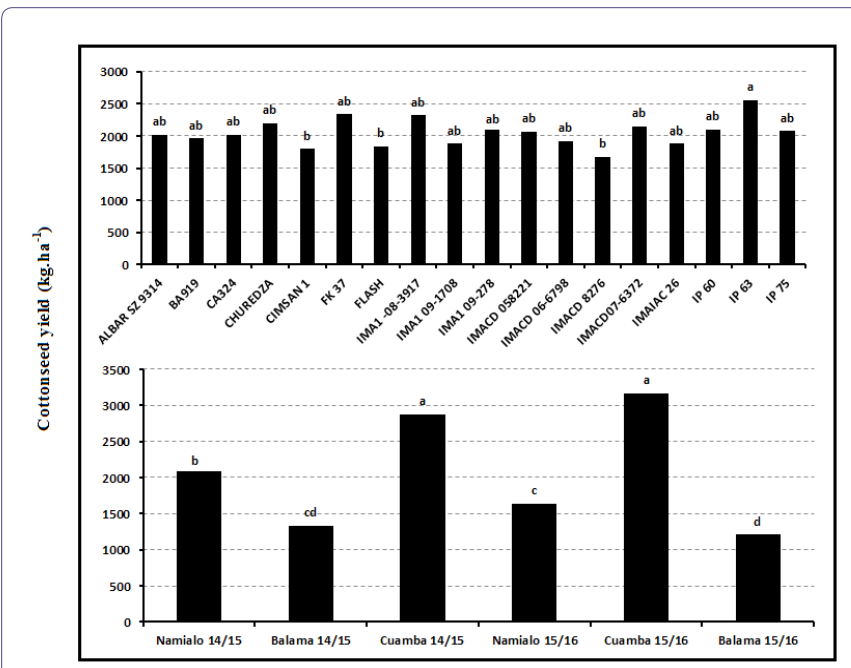

Figure 2: Comparison of cottonseed yield general mean $\left(\mathrm{kg}^{-\mathrm{ha}^{-1}}\right)$ of 18 genotypes evaluated in 6 environments.

Means with the same letter are not significantly different by Tukey's Studentized Range (HSD) Test.

\section{Conclusion}

The AMMI was useful to study the GxE interaction and to assess the stability and adaptability on the multi-environmental trial. The results illustrated that the genotypes and environments showed dissimilarity once they were positioned in opposing quadrants and the most stable genotypes across to the different environments were not the most adaptable. Thence, the most productive and adaptable new genotype in terms of seed cotton yield was IP63, but it was unstable. Among the introduced new genotypes, the Brazilian IMACD 06-6798 were classified as the most stable followed by the other 
Brazilian IMA1 08-3917 and the Turkish BA 919 compared to the local CIMSAN 1 and the Zambian Churedza. The results suggest that the genotypes IMACD 06-6798, IMA1 08-3917, BA 919 should be recommended for cultivation in Mozambique, since they presented an acceptable adaptability and potential stability.

\section{References}

1. International Trade Centre (2017) Cotton exporter's guide. ITC, Geneva, Switzerland.

2. Dias P (2012) Analysis of incentives and disincentives for cotton in Mozambique, technical notes series. FAO, Rome, Italy.

3. Instituto de Algodão de Moçambique (2015) Relatório sobre o ponto de situação do sub-sector de algodão. IAM, Maputo, Mozambique.

4. Mekuria K (2012) Practical examples of harnessing gains from commodity value chain development in Ethiopia. Paper presented at the Global Commodities Forum, Palais des Nations, Geneva.

5. Maleia MP, Vidigal-Filho PS, Kvitschal MV, Gonçalves-Vidigal MGC (2010) Stability and adaptability of commercial cotton cultivars (Gossypium hirsutum L. race latifolium H.) in Mozambique. Afr J Agric Res 5 : 539-550.

6. Pretorius MM, Allemann J, Smith MF (2015) Use of the AMMI model to analyse cultivar-environment interaction in cotton under irrigation in South Africa. Afr J Agric 2: 076-080.

7. Bartlett MS (1937) Properties of sufficiency and statistical tests. Proc R Soc A 160: 268-282.
8. Shapiro SS, Wilk MB (1995) An analysis of variance test for normality (complete samples). Biometrika 52: 591-611.

9. Hartley HO (1950) The use of range in analysis of variance. Biometrika 37: $271-280$

10. Cruz CD, Regazzi AJ (2001) Modelos biométricos aplicados ao melhoramento genético. UFV, Viçosa.

11. Zobel RW, Wrightm AJ, Gauch HG (1988) Statistical analysis of a yield trial. Agron J 80: 388-393.

12. Gauch HG (1988) Model selection and validation for trial with interaction. Biometrics. 88: 705-715.

13. Gauch HG (1992) Statistical analysis of regional yield trials: AMMI analysis of factorial designs. Elsevier, New York.

14. Cornelius PL, Crossa J, Seyedsadr MS (1996) Statistical tests and estimators of multiplicative models for genotype-by-environment interaction. In: Kang MS, Gauch HG (eds.). Genotype-by-environment interaction ( $2^{\text {nd }}$ edn). CRC Press, Boca Raton, USA.

15. Anandan A, Eswaran R, Sabesan T, Prakash M (2009) Additive main effects and multiplicative interactions analysis of yield performances in rice genotypes under coastal saline environments. Adv Biol Res 3: 43-47.

16. Maleia MP, Raimundo A, Moiana LD, Teca JO, Chale F, et al. (2017) Stability and adaptability of cotton (Gossypium hirsutum L.) genotypes based on AMMI analysis. Australian Journal of Crop Science 04: 367-372.

17. Gul S, Khan NU, Batool S, Balock, MJ, Munir M, et al. (2014) Genotype by environment interaction and association of morpho-yield variables in upland cotton. J Anim Plant Sci 24: 262-271. 


\section{Hit}

Journal of Anesthesia \& Clinical Care

Journal of Addiction \& Addictive Disorders

Advances in Microbiology Research

Advances in Industrial Biotechnology

Journal of Agronomy \& Agricultural Science

Journal of AIDS Clinical Research \& STDs

Journal of Alcoholism, Drug Abuse \& Substance Dependence

Journal of Allergy Disorders \& Therapy

Journal of Alternative, Complementary \& Integrative Medicine

Journal of Alzheimer's \& Neurodegenerative Diseases

Journal of Angiology \& Vascular Surgery

Journal of Animal Research \& Veterinary Science

Archives of Zoological Studies

Archives of Urology

Journal of Atmospheric \& Earth-Sciences

Journal of Aquaculture \& Fisheries

Journal of Biotech Research \& Biochemistry

Journal of Brain \& Neuroscience Research

Journal of Cancer Biology \& Treatment

Journal of Cardiology: Study \& Research

Journal of Cell Biology \& Cell Metabolism

Journal of Clinical Dermatology \& Therapy

Journal of Clinical Immunology \& Immunotherapy

Journal of Clinical Studies \& Medical Case Reports

Journal of Community Medicine \& Public Health Care

Current Trends: Medical \& Biological Engineering

Journal of Cytology \& Tissue Biology

Journal of Dentistry: Oral Health \& Cosmesis

Journal of Diabetes \& Metabolic Disorders

Journal of Dairy Research \& Technology

Journal of Emergency Medicine Trauma \& Surgical Care

Journal of Environmental Science: Current Research

Journal of Food Science \& Nutrition

Journal of Forensic, Legal \& Investigative Sciences

Journal of Gastroenterology \& Hepatology Research

Journal of Gerontology \& Geriatric Medicine
Journal of Genetics \& Genomic Sciences

Journal of Hematology, Blood Transfusion \& Disorders

Journal of Human Endocrinology

Journal of Hospice \& Palliative Medical Care

Journal of Internal Medicine \& Primary Healthcare

Journal of Infectious \& Non Infectious Diseases

Journal of Light \& Laser: Current Trends

Journal of Modern Chemical Sciences

Journal of Medicine: Study \& Research

Journal of Nanotechnology: Nanomedicine \& Nanobiotechnology

Journal of Neonatology \& Clinical Pediatrics

Journal of Nephrology \& Renal Therapy

Journal of Non Invasive Vascular Investigation

Journal of Nuclear Medicine, Radiology \& Radiation Therapy

Journal of Obesity \& Weight Loss

Journal of Orthopedic Research \& Physiotherapy

Journal of Otolaryngology, Head \& Neck Surgery

Journal of Protein Research \& Bioinformatics

Journal of Pathology Clinical \& Medical Research

Journal of Pharmacology, Pharmaceutics \& Pharmacovigilance

Journal of Physical Medicine, Rehabilitation \& Disabilities

Journal of Plant Science: Current Research

Journal of Psychiatry, Depression \& Anxiety

Journal of Pulmonary Medicine \& Respiratory Research

Journal of Practical \& Professional Nursing

Journal of Reproductive Medicine, Gynaecology \& Obstetrics

Journal of Stem Cells Research, Development \& Therapy

Journal of Surgery: Current Trends \& Innovations

Journal of Toxicology: Current Research

Journal of Translational Science and Research

Trends in Anatomy \& Physiology

Journal of Vaccines Research \& Vaccination

Journal of Virology \& Antivirals

Archives of Surgery and Surgical Education

Sports Medicine and Injury Care Journal

International Journal of Case Reports and Therapeutic Studies

Submit Your Manuscript: http://www.heraldopenaccess.us/Online-Submission.php 